\begin{tabular}{|c|l|}
\hline Title & $\begin{array}{l}\text { Redescription and Taxonomic Reassessment of Nemertellina minuta Friedrich, 1935, sensu Y amaoka, 1940 (Nemertea, } \\
\text { Hoplonemertea, Monostilifera) }\end{array}$ \\
\hline Author(s) & Kajihara, Hiroshi; Gibson, Ray; Mawatari, Shunsuke F. \\
\hline Citation & $\begin{array}{l}\text { Zoological Science, 17(2), 265-276 } \\
\text { https:/doi.org/L0.2108/2s.17.265 }\end{array}$ \\
\hline Issue Date & 2000-03 \\
\hline Doc URL & http://hdl.handle.net/2115/32937 \\
\hline Rights & (c) 日本動物学会/本文献の公開は著者の意思に基づくものである \\
\hline Type & article \\
\hline File Information & http_www.jstage.jst.go.pdf17(2)265.pdf \\
\hline
\end{tabular}

Instructions for use 


\title{
Redescription and Taxonomic Reassessment of Nemertellina minuta Friedrich, 1935, sensu Yamaoka, 1940 (Nemertea, Hoplonemertea, Monostilifera)
}

\author{
Hiroshi Kajihara $^{1 *}$, Ray Gibson ${ }^{2}$ and Shunsuke F. Mawatari ${ }^{1}$ \\ ${ }^{1}$ Division of Biological Sciences, Graduate School of Science, Hokkaido University, \\ Sapporo 060-0810, Japan \\ ${ }^{2}$ School of Biological and Earth Sciences, Liverpool John Moores University, \\ Byrom Street, Liverpool L3 3AF, U.K.
}

\begin{abstract}
Nemertellina minuta Friedrich, 1935, sensu Yamaoka, 1940, from Akkeshi Bay, Japan, is fully redescribed as a new species, Nemertellina yamaokai. The main characters distinguishing this taxon from $N$. minuta are the presence of two pairs of cephalic furrows and cephalic glands, and the absence of dorsoventral muscles from the intestinal region.
\end{abstract}

\section{INTRODUCTION}

The monostiliferous hoplonemertean genus Nemertellina was established by Friedrich (1935a) for two species that he described from Kiel Bay, Germany, Nemertellina canea Friedrich, 1935, and N. oculata Friedrich, 1935. In the same year Friedrich (1935b) described a third species, N. minuta Friedrich, 1935. The fourth species, N. tropica Kirsteuer, 1965, was subsequently described by Kirsteuer (1965) from a coral reef in Madagascar. There are no other records of Nemertellina species except for that of Yamaoka (1940), who reported a single specimen, identified as $N$. minuta, from "the canal of [a] sponge, collected from several metres depth in Akkeshi Bay" (Yamaoka, 1940: 240). He noted that the internal structure of the specimen "was not clearly observed" but that the individual appeared to be referable to $N$. minuta because of its small, slender white body, head with a rounded anterior margin, two pairs of eyes widely separated from each other, rhynchocoel restricted to the anterior region of the body, and conical stylet basis almost equal in length to that of the central stylet. Iwata's (1954) reference to N. minuta occurring in Japanese waters was based upon Yamaoka's (1940) record, of which Gibson (1995: 427) commented that "the validity of this occurrence is uncertain."

During 1997 and 1998 several specimens of a nemertean were collected from the same location in Akkeshi Bay as Yamaoka's (1940) original material. Their external appearance was identical to the species illustrated by Yamaoka (1940: text-fig. 15) as N. minuta. Histological studies of the anatomy of the present specimens confirm that they belong in the genus Nemertellina.

\footnotetext{
* Corresponding author: Tel. +81-11-706-3524; FAX. +81-11-746-0862.
}

\section{MATERIALS AND METHODS}

The nemerteans were obtained from 6-8 $\mathrm{m}$ depth at two sites dredged in Akkeshi Bay, Japan, at $43^{\circ} 00^{\prime} \mathrm{N}, 144^{\circ} 46^{\prime} \mathrm{E}$ and $43^{\circ} 42^{\prime} \mathrm{N}$, $144^{\circ} 51^{\prime} \mathrm{E}$. Dredgings were made on 9 July 1997, 15 April 1998 and 8-9 July 1998, all the samples comprising a mixture of bivalve molluscs (Patinopecten sp. and oysters), sponges, seaweeds and rocks. Each sample was placed in a container in the laboratory, covered with clean sea water and allowed to stand without aeration. Nemerteans emerging from the samples were removed over a 48-hr period, a total of 35 individuals being obtained from all the samples. Specimens for histological examination were anaesthetized in $7.5 \% \mathrm{MgCl}_{2}$, fixed in Bouin's solution for $24 \mathrm{hr}$, embedded in $56-57^{\circ} \mathrm{C}$ m.p. paraffin wax and sectioned at 5-6 $\mu \mathrm{m}$ before being stained with the Mallory trichrome method. A total of 12 specimens has been sectioned, 9 transversely and 3 longitudinally. Observations on the stylet apparatus of 32 specimens were made by the squeezing method described by Kirsteuer (1967).

Type material is deposited in the Zoological Institute, Hokkaido University, Japan(ZIHU) and the National Museum of Natural History, Smithsonian Institution, Washington, D.C., U.S.A. (USNM).

\section{RESULTS}

\section{DESCRIPTION}

Family Tetrastemmatidae Hubrecht, 1879 Genus Nemertellina Friedrich, 1935

Diagnosis: Friedrich (1935a) gave the following characters as diagnostic for the genus: tip of head with both circular and longitudinal musculature; four eyes; cerebral organs simple, not extending back to pre-cerebral septum, opening by pores near the anterior pair of eyes; no cephalic furrows; pre-cerebral septum closed but differently formed in the different species; rhynchocoel not extending into posterior third of body; a transverse muscle septum present in the body which is formed 
from the rhynchocoel circular muscle layer and constricts the intestine; intestine with shallow lateral diverticula; dorsoventral muscles weakly developed.

Friedrich's (1936) generic diagnosis for the genus was essentially the same, although he made no mention of the eye number. Kirsteuer (1965) noted that important anatomical features diagnostic of the genus Nemertellina included the position of the cerebral sensory organs in the tip of the head, a closed pre-cerebral septum, a short rhynchocoel reaching to between 50 and $66 \%$ of the body length, a single intestinal caecum, lateral nerve cords with a single neuropil, and a compact transverse septum in the vicinity of the caudal end of the rhynchocoel formed from the circular muscle fibres of the rhynchocoel wall. With the exception of rhynchocoel length and eye number, none of these features was recorded by Yamaoka.

\section{Nemertellina yamaokai sp. nov.}

(Figs 1-33)

Synonyms: Nemertellina minuta Yamaoka, 1940: 239-240, text-figs 15, 16; Iwata, 1954: 2, 15, Table 1.

Etymology: The species is named after Teiichi Yamaoka, both as a tribute to his work on the nemertean fauna of Japan and as the original finder of the present species.

Type specimens: Type specimens consist of the holotype, immature male, complete series of transverse sections, 26 slides (ZIHU-01260) and paratypes, female, series of transverse sections, 24 slides (ZIHU-01261), male, complete series of longitudinal sections, 14 slides (ZIHU-01262) and female, complete series of transverse sections, 17 slides (USNM 186063). Three unsectioned voucher specimens are also deposited under ZIHU-1271, ZIHU-1272 and ZIHU-1273. Type locality: Akkeshi Bay, Japan, 6-8 m depth among sponges, seaweeds, rocks and molluscs (Patinopecten sp. and oysters), $43^{\circ} 00^{\prime} \mathrm{N}, 144^{\circ} 46^{\prime} \mathrm{E}$.

Other locations: Akkeshi Bay, Japan, $43^{\circ} 42^{\prime} \mathrm{N}, 144^{\circ} 51^{\prime} \mathrm{E}$, similar depth and substrate to the type locality; Akkeshi Bay, in the canal of a sponge from several metres depth (Yamaoka, 1940).

External features: The body is slender, filiform and with an almost uniform width throughout its length (Figs 1, 2); specimens were from 7-30 mm long and 250-625 $\mu \mathrm{m}$ in diameter (Table 1). There is no distinct colour pattern, the anterior region being white, the intestinal region variously pure white to pale yellow. The cerebral ganglia are usually distinguishable by their reddish coloration. The anteriorly rounded head is not wider than the adjacent body, the posterior end is slightly pointed. The four distinct eyes are arranged to form the corners of an elongate rectangle (Fig. 1A). There are two pairs of cephalic furrows (Fig. 1), one pair behind each pair of eyes. The anterior furrows curve forward on the ventral surface, meeting to form a longitudinal median groove that extends towards the tip of the head (Fig. 1B), the posterior furrows completely encircle the head, forming a posteriorly directed V-shape on its dorsal surface (Fig. 1A). Approximately onethird of the distance along the body there is a distinct epider- mal constriction (Figs 1-3), situated just in front of the posterior end of the rhynchocoel.

Body wall, musculature and parenchyma: The ciliated and glandular epidermis (Fig. 4) is $12-30 \mu \mathrm{m}$ thick, but with few acidophilic gland cells in the ventral pre-cerebral regions of the head (Figs 4-7) compared with other regions of the body. Basally the epidermis possesses a distinct basal-cup zone, as described by Norenburg (1985). The dermis is only 1-7 $\mu \mathrm{m}$ thick but distinct (Fig. 8). The body wall musculature is most strongly developed in the foregut region; the circular muscle layer (Fig. 8), extending the full length of the body, has a maximum thickness of $5-6 \mu \mathrm{m}$ but is mostly less than this, while the longitudinal musculature (Fig. 8) is $10-30 \mu \mathrm{m}$ deep in the anterior regions but caudally reduced to only 5-7 $\mu \mathrm{m}$. The longitudinal layer is not anteriorly divided, as in several monostiliferous genera, most of its fibres pre-cerebrally turning inwards to form the proboscis insertion (Fig. 7), although isolated fibres or fibre bundles continue anteriorly as the cephalic retractor muscles.

Throughout the cephalic region many of the longitudinal fibres turn inwards to contribute to a loose meshwork of fibres which extends between the cephalic glands surrounding the rhynchodaeum (Fig. 4). There is no diagonal muscle layer in the body wall, nor was evidence of dorsoventral muscle bundles found in any part of the body.

Parenchymatous connective tissues are but sparingly developed throughout the body.

Proboscis apparatus: The subterminal, ventral proboscis pore opens from the longitudinal median groove formed by the anterior pair of cephalic furrows. The rhynchodaeal epithelium is delicate, mostly $2-5 \mu \mathrm{m}$ thick but reaching a depth of about $10 \mu \mathrm{m}$ just in front of the proboscis insertion (Figs 4, 9$11)$, but neither ciliated nor glandular. There is no rhynchodaeal sphincter.

The rhynchocoel is between $30-60 \%$ of the body length. Its wall contains separate circular and longitudinal muscle layers, each mostly only one or two fibres thick. In that portion of the body where the proboscis retractor muscle is attached to the rhynchocoel wall the circular muscle layer is dissolved to form an intestinal sphincter (Figs 12, 13), corresponding in position to the epidermal annular constriction.

The proboscis, slightly longer than the rhynchocoel, possesses a typical monostiliferous construction as described by Gibson (1972). The most anterior portion of the proboscis, leading from the proboscis insertion, is short, only 35-50 $\mu \mathrm{m}$ in diameter and composed only of a longitudinal muscle layer about $15 \mu \mathrm{m}$ in maximum thickness flanked on its inner and outer surfaces by a thin connective tissue lining. The main anterior region (Fig. 14) in the retracted position, however, is $45-60 \%$ of the overall body diameter and comprises a papillate epithelium 40-70 $\mu \mathrm{m}$ tall, a connective tissue basement layer, a delicate outer circular muscle layer only 2-3 fibres thick, an inner longitudinal muscle coat 7-20 $\mu \mathrm{m}$ across, a delicate inner connective tissue membrane and a flattened inner lining. The 9-10 proboscis nerves are generally small and indistinct; they run in the longitudinal muscle layer and 


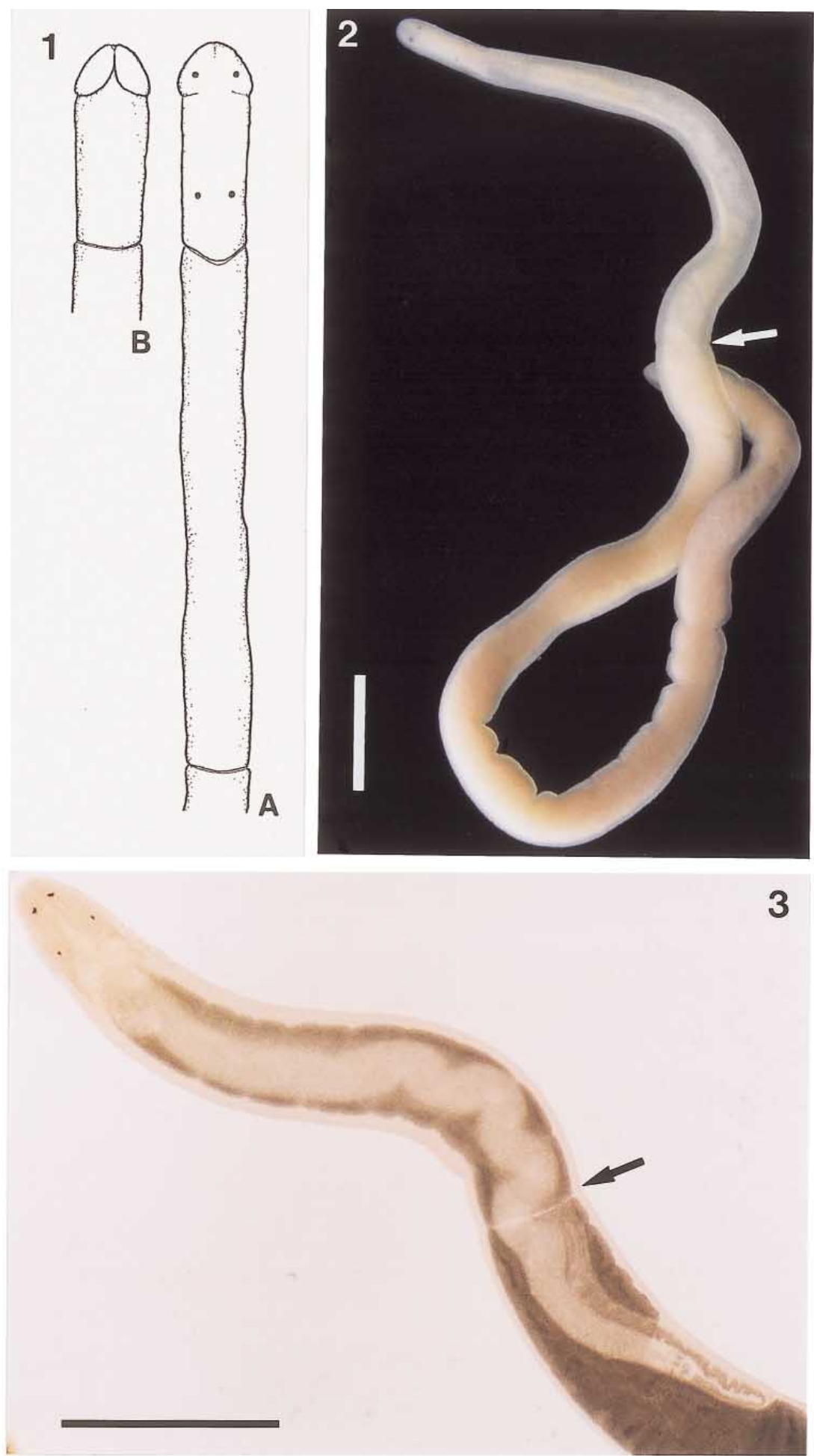

Figs 1-3. Nemertellina yamaokai sp. nov. 1. Drawings to show the external features of the anterior region viewed from dorsal (A) and ventral (B) aspect. Redrawn from Yamaoka's (1940: text-fig. 15) illustration of the specimen he identified as Nemertellina minuta. 2. Photograph of a living specimen, viewed dorsally. The arrow indicates the position of the annular epidermal constriction. 3. Photomicrograph of the anterior body region of an anaesthetized and squeezed specimen, showing the annular epidermal constriction (indicated by the arrow), cerebral ganglia, proboscis and arrangement of the eyes. The distance between anterior and posterior pairs of eyes compared to that observed in freely moving individuals is decreased as a consequence of contraction. Scale bars $=1 \mathrm{~mm}$. 
Table 1. The body lengths and widths, central stylet and basis lengths and number of accessory stylet pouches and their contained reserve stylets recorded for 33 specimens of Nemertellina yamaokai sp. nov.

\begin{tabular}{|c|c|c|c|c|c|c|}
\hline $\begin{array}{l}\text { Specimen } \\
\text { number }\end{array}$ & $\begin{array}{c}\text { Body } \\
\text { length in mm }\end{array}$ & $\begin{array}{c}\text { Body } \\
\text { width in } \mu \mathrm{m}\end{array}$ & $\begin{array}{l}\text { Length of } \\
\text { central stylet } \\
\text { in } \mu \mathrm{m}\end{array}$ & $\begin{array}{l}\text { Length of } \\
\text { stylet basis } \\
\text { in } \mu \mathrm{m}\end{array}$ & $\begin{array}{c}\text { Number of } \\
\text { accessory stylet } \\
\text { pouches }\end{array}$ & $\begin{array}{c}\text { Numbers of } \\
\text { accessory stylets per } \\
\text { pouch }\end{array}$ \\
\hline 1 & 7 & 250 & 43 & 43 & 2 & 4,4 \\
\hline 2 & 18 & 300 & 51 & 65 & 2 & 4,4 \\
\hline 3 & 14 & 380 & 53 & 53 & $?$ & $?$ \\
\hline 4 & 16 & 400 & 58 & 59 & 2 & 6,3 \\
\hline 5 & 11 & 380 & 63 & 56 & 2 & 5,4 \\
\hline 6 & 16 & 500 & 59 & 60 & 2 & 4,4 \\
\hline 7 & 13 & 280 & 51 & 51 & 2 & 3,3 \\
\hline 8 & 15 & 350 & 53 & 49 & 2 & 3,3 \\
\hline 9 & 14 & 250 & 51 & 53 & 2 & 4,3 \\
\hline 10 & 18 & 380 & 46 & 48 & 2 & 3,3 \\
\hline 11 & 16 & 280 & 63 & 55 & 2 & 4,3 \\
\hline 12 & 20 & 500 & 61 & 58 & 2 & 4,3 \\
\hline 13 & 10 & 380 & 59 & 51 & 2 & 4,4 \\
\hline 14 & 30 & 625 & 59 & 59 & 2 & 4,3 \\
\hline 15 & 8 & 500 & 45 & 53 & 2 & 4,4 \\
\hline 16 & 10 & 450 & 53 & 48 & 2 & 7,5 \\
\hline 17 & 14 & 375 & 42 & 54 & 2 & 4,3 \\
\hline 18 & 13 & 375 & $A$ & $A$ & 2 & 1,2 \\
\hline 19 & 10 & 450 & 37 & 53 & 2 & 4,5 \\
\hline 20 & 13 & 375 & 49 & 53 & 2 & 4,3 \\
\hline 21 & 20 & 500 & 51 & 64 & 2 & 4,4 \\
\hline 22 & 12 & 500 & 53 & 57 & 2 & 4,5 \\
\hline 23 & 12 & 375 & 49 & 55 & 2 & 4,4 \\
\hline 24 & 25 & 500 & 54 & 53 & 2 & 4,5 \\
\hline 25 & 17 & 375 & 53 & 49 & 2 & 3,3 \\
\hline 26 & 17 & 450 & 60 & 59 & 2 & 3,3 \\
\hline 27 & 13 & 375 & 52 & 58 & 2 & 4,5 \\
\hline 28 & 7 & 370 & 47 & 45 & 4 & $3,3,3,2$ \\
\hline 29 & 25 & 625 & 43 & 60 & 2 & 3,3 \\
\hline 30 & 7 & 380 & 38 & 44 & 2 & 4,3 \\
\hline 31 & 15 & 500 & 50 & 58 & 3 & $4,3,3$ \\
\hline 32 & 28 & 450 & 49 & 61 & 2 & 4,5 \\
\hline 33 & 20 & 500 & 45 & 60 & 2 & 6,7 \\
\hline Mean \pm S.E. & $15.27 \pm 5.77$ & $414.55 \pm 93.08$ & $51.25 \pm 6.70$ & $54.50 \pm 5.35$ & $2.09 \pm 0.38$ & $3.78 \pm 1.04$ \\
\hline
\end{tabular}

$?=$ not recorded

$A=$ missing from proboscis

are peripherally linked by delicate interneural connectives (Fig. 14).

The stylet bulb region (Figs 15, 16) conforms to the generalised monostiliferous condition described by Gibson (1972). The central stylet (Fig. 17) is smooth and 37-63 $\mu \mathrm{m}$ long (Table 1), its basis 43-65 $\mu \mathrm{m}$ long and with a tapered cylindrical shape. The stylet : basis ratio varies from $1: 0.86$ to $1: 1.43$ with an average value of $1: 1.08$. In most individuals there are two accessory stylet pouches, each typically containing four or five reserve stylets (range 1-7) (Fig. 16), although one individual possessed three accessory pouches and one had four (Table 1).

The posterior portion of the proboscis (Fig. 18) is about $30-40 \%$ of the body diameter; it possesses neither epithelial papillae nor an obvious neural supply. Its outer longitudinal muscle layer is $2-5 \mu \mathrm{m}$ thick, whereas its inner circular muscle layer is extremely thin and poorly developed.

Alimentary canal: The oesophagus (Figs 4, 19, 20) is thinwalled, 2-10 $\mu \mathrm{m}$ in diameter, and neither ciliated nor glandu- lar. It emerges from the ventral floor of the rhynchodaeum close in front of the proboscis insertion, leading posteriorly to merge with the stomach behind the brain. The transition between oesophagus and stomach is marked by the appearance of cilia and basophilic gland cells (Fig. 19). The stomach (Figs 8, 21, 23) wall is not deeply folded, its epithelium, which is dominated by basophilic glands, decreasing in thickness from an anterior height of about $50 \mu \mathrm{m}$ commensurate with a posterior decline in the density of gland cell numbers as it approaches the slender pyloric canal (Fig. 22).

From the junction between the pylorus and intestine a short intestinal caecum (Fig. 23) extends anteriorly below the rear half of the stomach. The caecum possesses neither anterior nor lateral diverticula. The intestine is simple, with paired shallow lateral pouches (Fig. 24) and opens via the anus at the extreme posterior tip of the body.

Blood system: The organization of the blood system broadly resembles the basic hoplonemertean pattern illustrated by Gibson (1972: fig. 14A). The anterior cephalic loop leads to a 

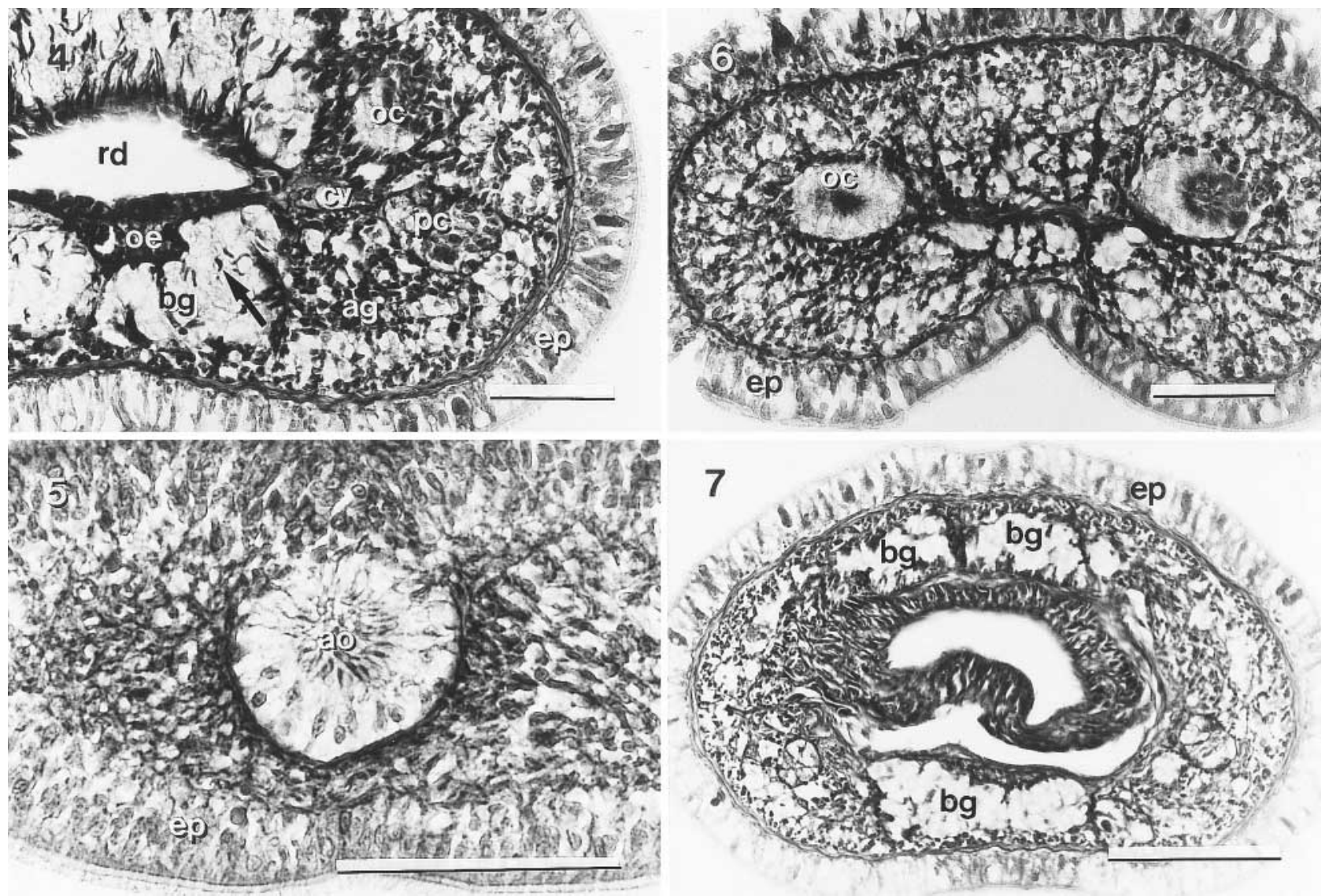

Figs 4-7. Nemertellina yamaokai sp. nov. 4. Transverse section through a posterior eye (oc); note the head retractor muscle fibres indicated by an arrow running through the basophilic cephalic glands (bg). 5. Transverse section through the tip of the head to show the apical organ (ao). 6 . Transverse section through the anterior pair of eyes. 7. Transverse section through the proboscis insertion. ag =acidophilic gland cells; $\mathrm{cv}=\mathrm{cephalic}$ blood vessel; $\mathrm{ep}=$ epidermis; oe =oesophagus; $\mathrm{pc}=$ posterior portion of cerebral organ; $r d=$ rhynchodaeum. Scale bars: $4-6=50 \mu \mathrm{m} ; 7=100 \mu \mathrm{m}$

pair of cephalic vessels which at first flank the rhynchodaeum as they run posteriorly (Figs 9-10), but farther back come into close contact with the medial parts of the posterior region of the cerebral sensory organs (Figs 4,11 ). As they pass through the cerebral ring the vessels protrude into the rhynchocoel (Fig. 19) to form a pair of thin-walled and flattened vascular plugs. Post-cerebrally the vessels continue back close to the lateral nerve cords, meeting near the tail by a supraintestinal connective. The origin of the mid-dorsal blood vessel is unusually far back, behind the brain region; it emerges as a branch from one of the lateral vessels between the anterior and posterior stomach regions of the body to extend posteriorly close to the ventral rhynchocoel wall (Fig. 12) or, behind the end of the rhynchocoel, above the intestine (Fig. 24). At its posterior end the mid-dorsal vessel joins the supraintestinal connective. There are no pseudometameric transverse connectives between the three longitudinal vessels in any part of the body.

Nervous system: The moderately large cerebral ganglia are transversely linked by a thin $(6-10 \mu \mathrm{m})$ dorsal commissure and thicker (17-40 $\mu \mathrm{m})$ ventral commissure, the former situated somewhat in front of or directly above the latter. The ganglia are enclosed by a thin but distinct outer neurilemma, but there is no inner neurilemma between the fibrous and ganglionic components of the brain. The lateral nerve cords contain one or two myofibrillae (Fig. 25), but possess neither accessory nerves nor neurochords. The lateral nerves meet posteriorly by a supraintestinal commissure.

Several cephalic nerves extend from the anterior and lateral margins of each cerebral lobe. One pair of nerves from the dorsal ganglia connect to the cerebral sensory organs, others appear to lead to the eyes and proboscis. From each ventral lobe a distinct lateroventral nerve emerges just behind the ventral commissure, passes through the outer neurilemma and continues posteriorly alongside the brain to the anterior stomach region, where it turns ventrally towards the stomach wall; these two nerves apparently innervate the stomach but their ultimate fate could not be traced. There is no mid-dorsal nerve.

Excretory system: The excretory system is mainly located on either side of the rhynchocoel (Figs 8, 23), extending from the posterior region of the stomach forwards to the lateral margins of the brain. The collecting tubules have a maximum diameter of about $25 \mu \mathrm{m}$ and possess thick walls, up to $12 \mu \mathrm{m}$ across. Near their anterior limits the tubule on each side of the body leads to an efferent duct which turns ventrolaterally to open by a single nephridiopore about $10 \mu \mathrm{m}$ in diameter; the position of the nephridiopores appears to depend upon 

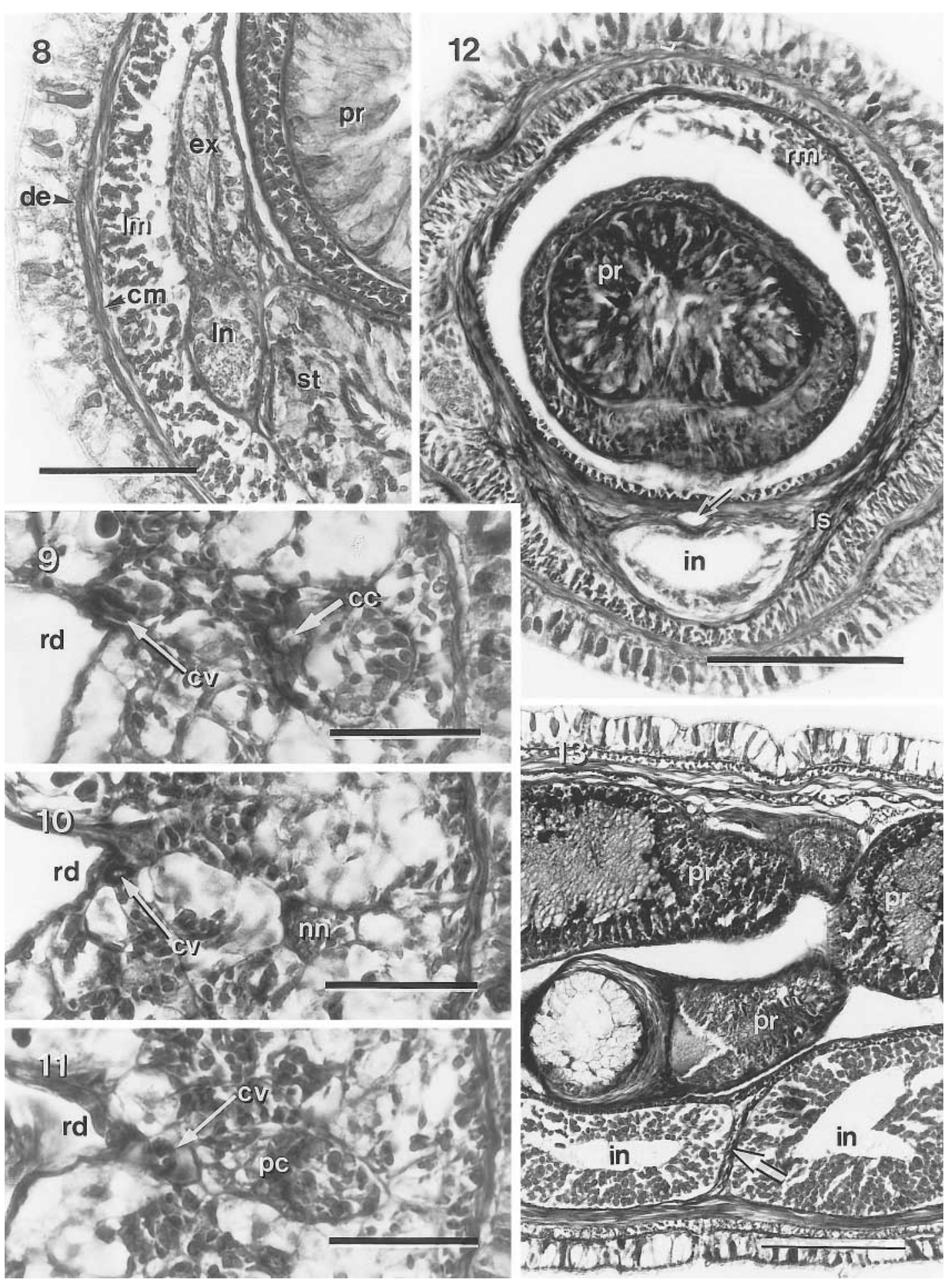

Figs 8-13. Nemertellina yamaokai sp. nov. 8. Transverse section through the stomach (st) region to show the lateral position of the excretory collecting tubules (ex). 9. Transverse section through the anterior portion of a cerebral organ, showing a ciliated cerebral canal (cc) indicated by the larger arrow. A cephalic blood vessel (cv) is indicated by the smaller arrow. 10. Transverse section through the narrowed 'neck' (nn) connecting the anterior and posterior regions of a cerebral organ. A cephalic blood vessel (cv) is arrowed. 11. Transverse section through the posterior portion (pc) of a cerebral organ to show its close association with a cephalic blood vessel (cv), indicated by an arrow. 12. Transverse section at the level of the epidermal annular constriction of one of the paratypes to show the sphincter (is) formed by the circular muscle layer of the rhynchocoel wall and the constricted portion of the intestine (in) where it passes through this sphincter. The arrow indicates the mid-dorsal blood vessel. 13. Longitudinal section through the intestinal sphincter, arrowed, of another paratype. $\mathrm{cm}=$ body wall circular muscle layer; $\mathrm{de}=$ dermis; $\mathrm{Im}=$ body wall longitudinal muscle layer; $\mathrm{In}=$ lateral nerve cord; $\mathrm{pr}=$ proboscis; $r d=$ rhynchodaeum; $r \mathrm{rm}=$ proboscis retractor muscle. Scale bars: $8,12,13=100 \mu \mathrm{m} ; 9-11=40 \mu \mathrm{m}$. 


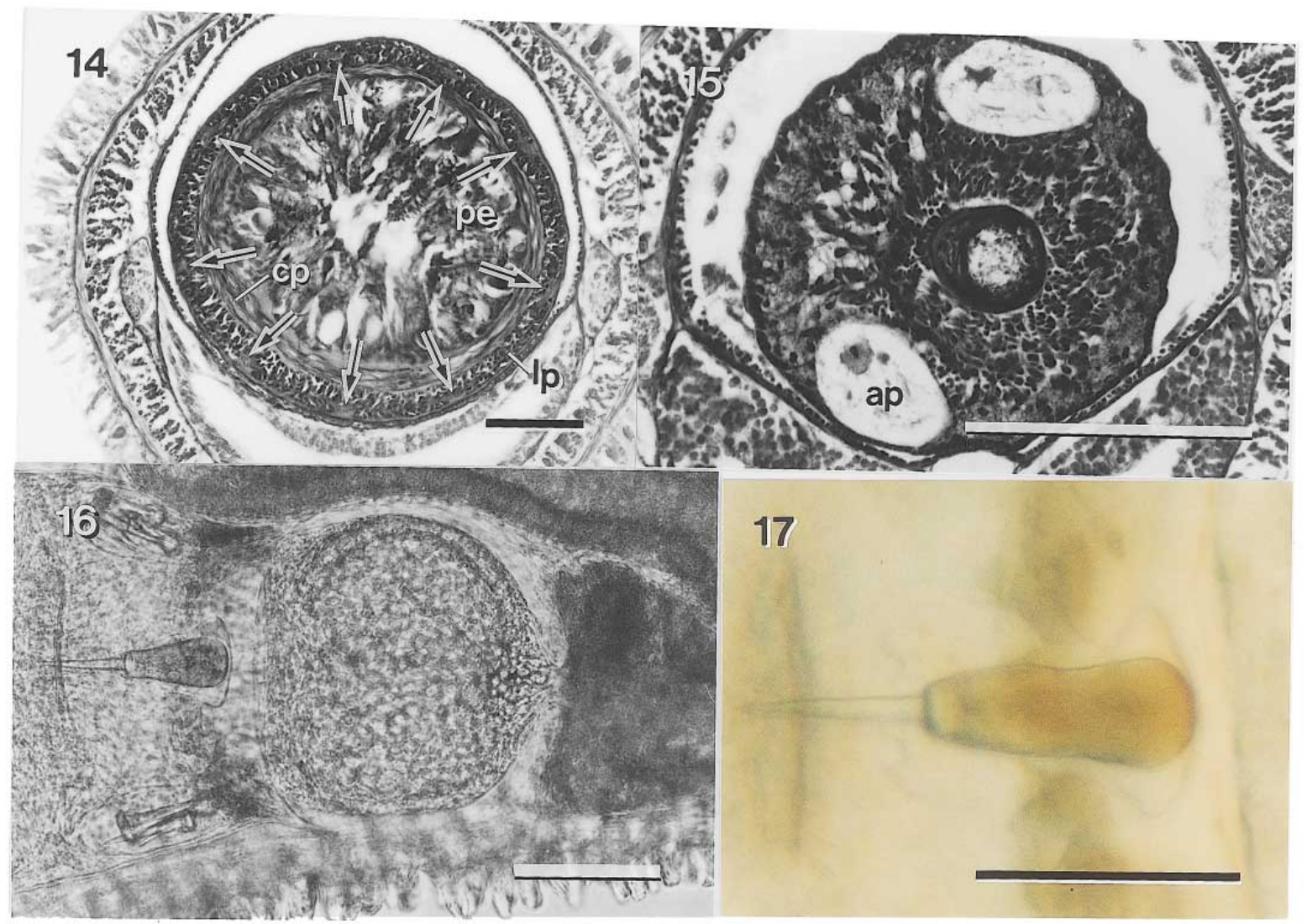

Figs 14-17. Nemertellina yamaokaisp. nov. 14. Transverse section through the main anterior portion of the proboscis; the 9 proboscis nerves are indicated by arrows. 15. Transverse section through the stylet bulb region of the proboscis showing the two accessory stylet pouches (ap). 16. Photomicrograph of the proboscis stylet bulb region of a living individual. 17. Nomarski differential interference contrast photomicrograph of a typical central stylet and basis, taken in a living specimen. $\mathrm{cp}=$ circular muscle layer of proboscis; Ip=longitudinal muscle layer of proboscis; pe $=$ proboscis epithelium. Scale bars: $14,17=50 \mu \mathrm{m} ; 15,16=100 \mu \mathrm{m}$.

the degree of body contraction but is located between the posterior brain (Fig. 26) and anterior stomach regions.

Apical organ and cephalic glands: The single apical or frontal organ opens close in front of the proboscis pore. It comprises a ciliated pit, 15-60 $\mu \mathrm{m}$ in diameter, lined by an epithelium 5-25 $\mu \mathrm{m}$ thick which completely lacks gland cells (Fig. 5). The cephalic glands discharge to the exterior through the apical organ. The typical, basophilic, vacuolate cephalic glands extend back to the proboscis insertion, occasionally beyond this to reach the anterior brain regions (Figs 7, 26). The glands mainly form two compact elongate masses, one mid-dorsal and the other mid-ventral (Fig. 7). The ventral mass often incompletely encloses the oesophagus above it, and usually extends farther back than the dorsal mass (Fig. 27).

Ocelli: There are four well-developed pigment cup ocelli, each approximately $25-50 \mu \mathrm{m}$ in diameter. The anterior pair is situated close to the tip of the head, the posterior pair just in front of the proboscis insertion (Figs 4, 5).

Cerebral organs: Each of the two cerebral organs opens by a ventrolateral ciliated canal, $15-20 \mu \mathrm{m}$ in diameter, which leads inwards from the anterior cephalic furrows (Fig. 28). The organs possess a simple construction and an elongate hourglass shape, forming anterior and posterior lobes which are medially joined by a narrower 'neck' (Figs 28-31). The ciliated canals terminate in a chamber medially flanked by gland cells in the anterior lobe. The anterior lobe is about $50 \mu \mathrm{m}$ in diameter. Behind this the 'neck', consisting mainly of neuroganglionic tissues but with a few gland cells interspersed between them, is only $5-12 \mu \mathrm{m}$ wide (Fig. 10), whereas the posterior lobe, containing both glandular and neural components, is about $45 \mu \mathrm{m}$ in maximum diameter. The cerebral organ nerve leads directly from the posterior end of each cerebral organ.

Reproductive system: The sexes are separate. The spherical gonads are restricted to the intestinal region of the body, forming a row on each side and broadly alternating with the lateral intestinal pouches. Mature specimens, with their gonads containing either ova or spermatids (Figs 32, 33), were collected in July. The gonopores open laterodorsally above the lateral nerve cords.

\section{SYSTEMATIC DISCUSSION}

Yamaoka (1940) gave only a brief description of the single individual he identified as Nemertellina minuta, commenting (p. 240) that the "specimen seems to be referable to [this spe- 


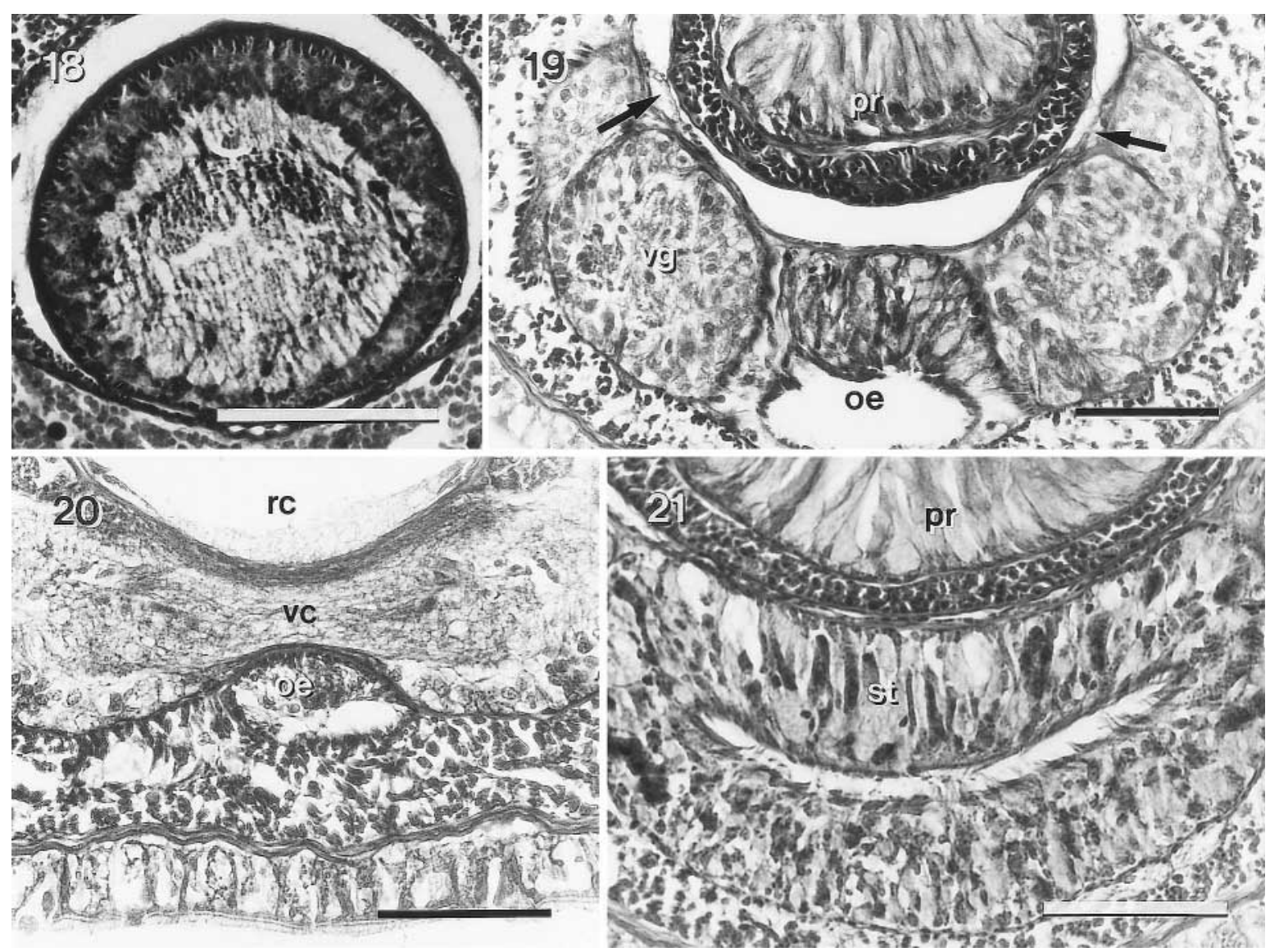

Figs 18-21. Nemertellina yamaokai sp. nov. 18. Transverse section through the posterior region of the proboscis. 19. Transverse section through the posterior brain region to show the two protrusions of the cephalic blood vessels, indicated by arrows, into the rhynchocoel wall. 20. Transverse section through the ventral cerebral commissure (vc). 21. Transverse section through the stomach (st). oe=oesophagus; pr =proboscis; $\mathrm{rC}=$ rhynchocoel; $\mathrm{vg}=$ ventral cerebral ganglion. Scale bars: $18=100 \mu \mathrm{m} ; 19-21=50 \mu \mathrm{m}$.

cies] by the following features; (1) the body is very small and slender, and is white in colour, and the head is rounded in the frontal margin, (2) two pairs of ocelli are separated by a long distance from each other, (3) the proboscis sheath extends only to the anterior region of the body, and (4) the basis of central stylet is conical, with the length almost equal to that of the stylet." The present material, collected from the same locality that Yamaoka obtained his specimen, possesses all of the above features and, in external appearance, is virtually identical to that illustrated by Yamaoka (1940: text-fig. 15A, B), including the presence of two pairs of cephalic furrows. The only known difference between our examples and Yamaoka's specimen is the body length; the longest of the present individuals measured was $30 \mathrm{~mm}$, whereas Yamaoka's specimen had a length of $50 \mathrm{~mm}$ (misprinted as "50 mm wide" in Yamaoka, 1940: 239). Although his original material, "cut into pieces in the fixiative" (ibid., p. 240), was lost, the close similarity between Yamaoka's and our specimens, especially as they came from the same location, fully justify them being regarded as conspecific.

Yamaoka's (1940: 239, text-fig. 15A, B) account and illustrations of the external features of his specimen are, however, at variance with Friedrich's $(1935 a, 1936,1955)$ generic diagnosis of Nemertellina in that both it and the present mate- rial possess two pairs of cephalic furrows, whereas $N$. canea, $N$. minuta and $N$. oculata completely lack cephalic furrows. Kirsteuer (1965) makes no reference to the presence of cephalic furrows in his description of the external features of $N$. tropica, referring to the cerebral organs (p. 305) as opening "mit einem ventrolateralen Porus, welcher sich am oberen Ende einer histologisch nicht als Kopffurche gekennzeichneten Eintellung befindet." The presence of two pairs of cephalic furrows in both Yamaoka's and the present specimens thus precludes them from being identifiable with $N$. minuta or with any of the other known members of the genus.

Table 2 summarises the major anatomical features of the present specimens compared with those described for the four previously known species of Nemertellina, and there is little doubt that the Japanese taxon should be included in this genus, particularly by the nature and position of its cerebral organs, possession of a closed pre-cerebral septum and short rhynchocoel, by the general organization of its alimentary canal with a short intestinal caecum and shallow lateral intestinal pouches and, especially, by the presence of its mid-body transverse muscular septum which forms a constriction around the intestine. On the basis of these similarities we believe that it would be unjustifiable to exclude the Japanese specimens from the genus Nemertellina merely on the grounds that they 

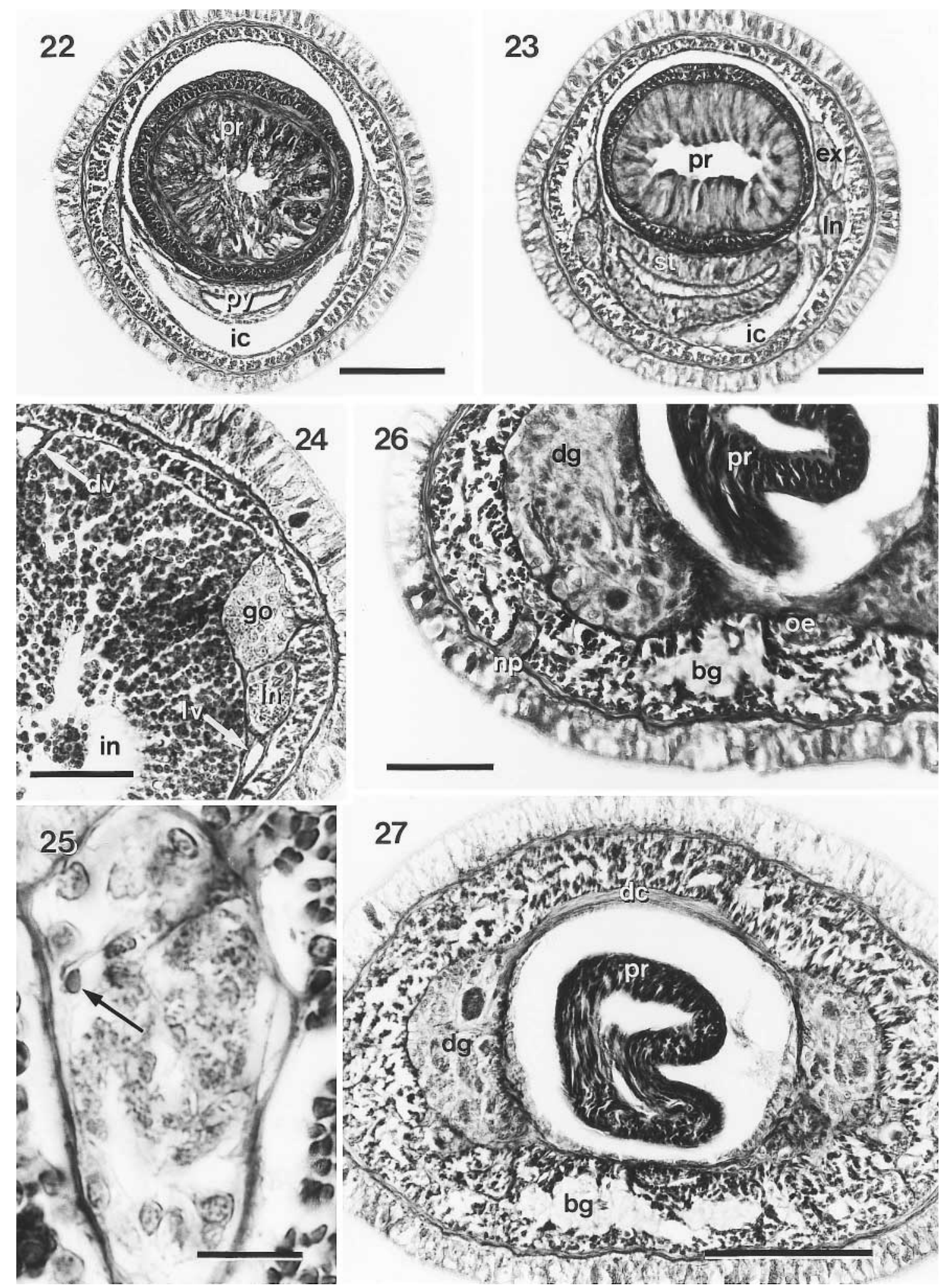

Figs 22-27. Nemertellina yamaokai sp. nov. 22. Transverse section through the pyloric portion (py) of the foregut. 23. Transverse section through the intestinal caecum (ic). 24. Transverse section through the intestine (in) of the holotype to show the distribution of the immature gonads (go). Mid-dorsal (dv) and lateral (lv) blood vessels are indicated by arrows. 25. Transverse section through a lateral nerve cord in the intestinal region; the arrow indicates a myofibrilla. 26. Transverse section through the posterior brain region to show a ventrolateral nephridiopore (np). 27. Transverse section through the brain region at the level of the dorsal cerebral commissure (dc). bg=basophilic cephalic glands; $d g=$ dorsal cerebral ganglion; $I n=$ lateral nerve cord; oe=oesophagus; $p r=$ proboscis. Scale bars: $22,23,27=100 \mu \mathrm{m} ; 24,26=50 \mu \mathrm{m} ; 25=10 \mu \mathrm{m}$. 

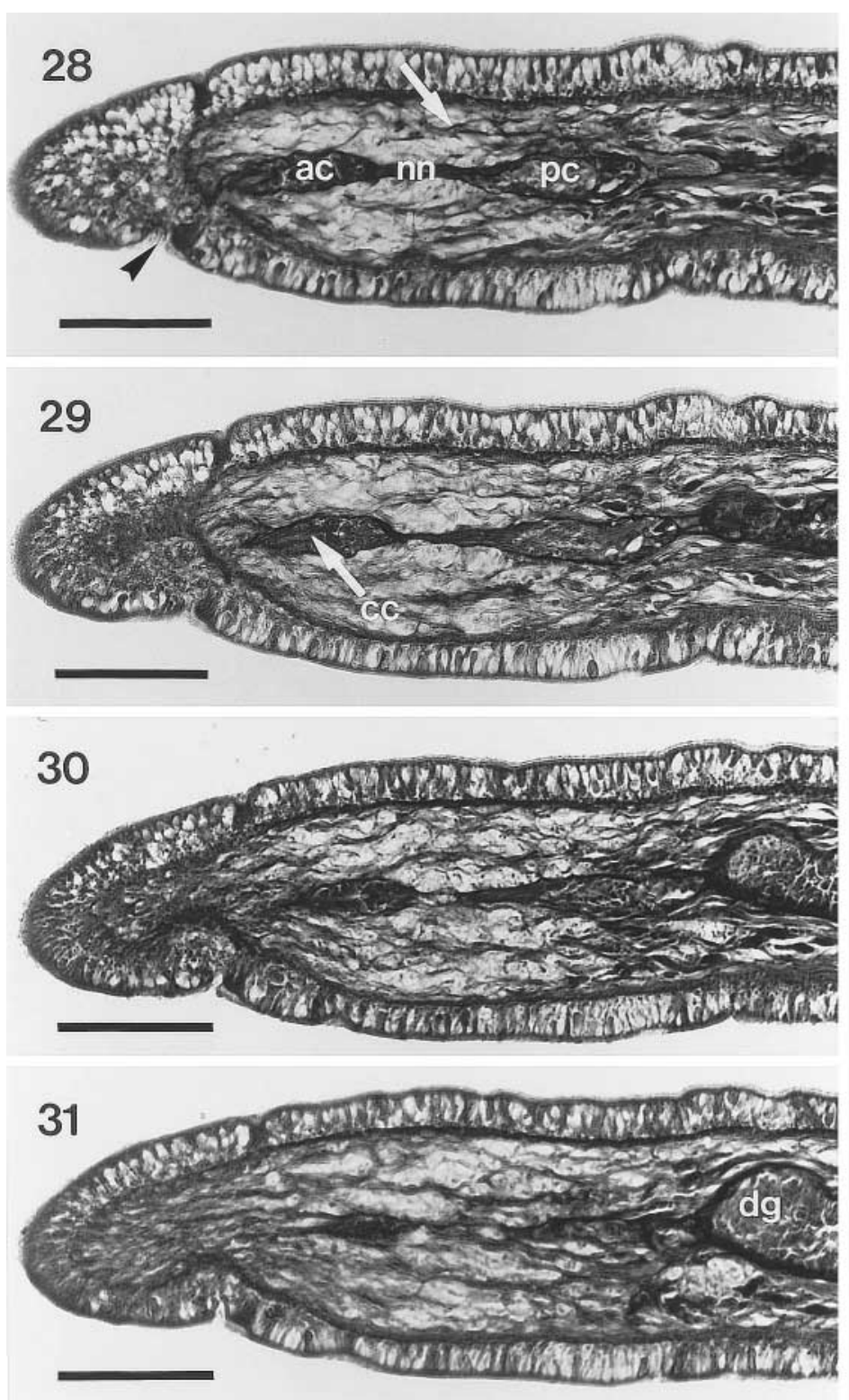
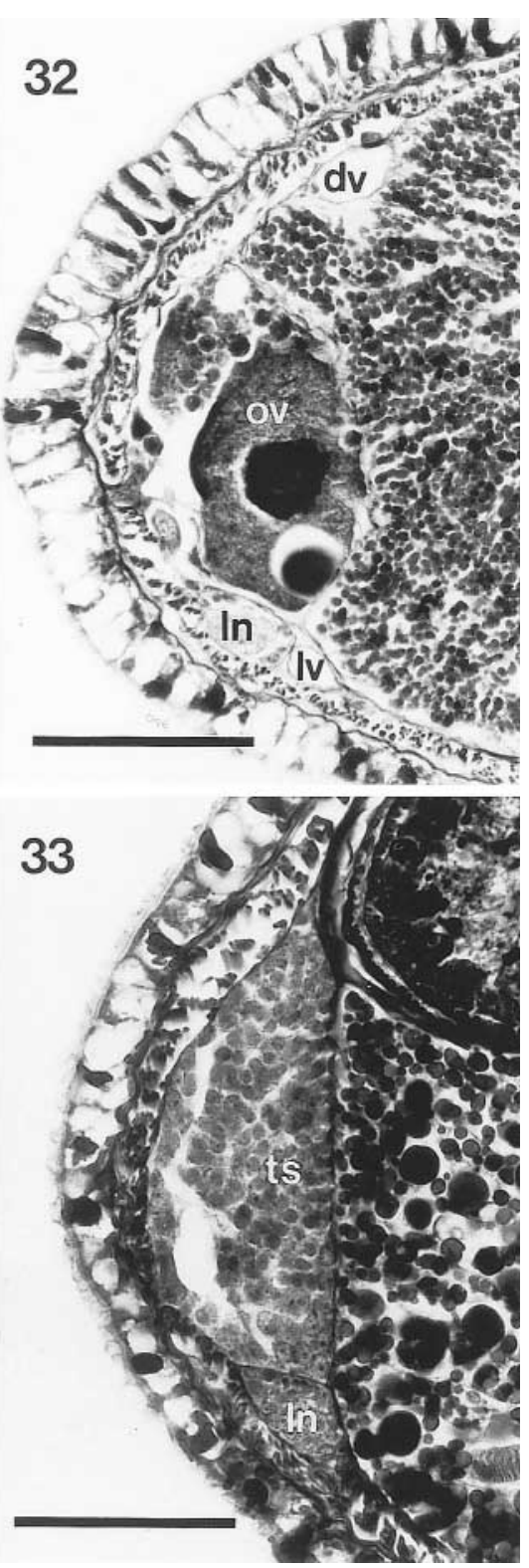

Figs 28-33. Nemertellina yamaokai sp. nov. 28-31. Serial longitudinal sections through the pre-cerebral region to show the ciliated cerebral canal (cc), anterior (ac) and posterior (pc) portions of a cerebral organ and the narrowed 'neck' (nn) which connects them. The arrowhead in Fig. 28 indicates an anterior cephalic furrow, the arrow a longitudinal muscle fibre. 32. Transverse section through the intestinal region of a mature female paratype to show the position of the ovaries (ov). 33. Transverse section to show a testis (ts) in a mature male paratype. $d g=d o r s a l$ cerebral ganglion; dv=mid-dorsal blood vessel; In=lateral nerve cord; Iv=lateral blood vessel. Scale bars: $28-32=100 \mu \mathrm{m} ; 33=50 \mu \mathrm{m}$.

possess cephalic furrows whereas other species do not; other monostiliferous genera are known, for example Tetrastemma, in which different species may possess two, one or no pairs of cephalic furrows (Gibson, 1994).

Several of the morphological features described for the present species cannot be compared with those of the previously known taxa; for example none of Friedrich's descriptions gives any information on the arrangement of the blood system, and Kirsteuer (1965) merely notes that in N. tropica the mid-dorsal vessel arises by branching off the left lateral vessel and does not enter the rhynchocoel wall. Nevertheless, the Japanese species can be distinguished from all the other known members of the genus Nemertellina by the fol- lowing characters: from all four species by its possession of cephalic furrows; from N. minuta by its possession of cephalic glands and lack of dorsoventral musculature in the intestinal region; from $N$. oculata by having no median dorsal nerve nor posterior rhynchodaeal sac; and from $N$. tropica by possessing only two muscle layers in the wall of the main anterior proboscis chamber and in lacking the dorsal appendix development at the junction between foregut and intestine. The species from Akkeshi Bay is accordingly redescribed above as Nemertellina yamaokai sp. nov.

In the light of the present studies a revised diagnosis for the genus Nemertellina is provided:

Diagnosis: Monostiliferous marine hoplonemerteans; 
Table 2. Anatomical characters of the present nemerteans from Japan compared with those of the four previously described species of Nemertellina. Data obtained from Friedrich (1935a, b), Kirsteuer (1965) and the present studies.

\begin{tabular}{|c|c|c|c|c|c|}
\hline Character & N. canea & N. minuta & N. oculata & N. tropica & Present species \\
\hline \multicolumn{6}{|l|}{ A. Features shared by all five taxa } \\
\hline $\begin{array}{l}\text { Tip of head containing both } \\
\text { circular and longitudinal body } \\
\text { wall muscle layers }\end{array}$ & + & + & + & + & + \\
\hline $\begin{array}{l}\text { Cerebral organs small, simple, } \\
\text { situated far anterior to brain } \\
\text { lobes and opening near the tip of } \\
\text { the head }\end{array}$ & + & + & + & + & + \\
\hline $\begin{array}{l}\text { Rhynchocoel not extending into } \\
\text { posterior third of body }\end{array}$ & + & + & + & + & + \\
\hline $\begin{array}{l}\text { Rhynchocoel wall containing } \\
\text { separate circular and longitudinal } \\
\text { muscle layers }\end{array}$ & + & + & + & + & + \\
\hline $\begin{array}{l}\text { Transverse muscle septum formed } \\
\text { from rhynchocoel wall circular } \\
\text { musculature present in intestinal } \\
\text { region and forming constriction } \\
\text { around intestine }\end{array}$ & + & + & + & + & + \\
\hline $\begin{array}{l}\text { Intestine with single anterior caecum } \\
\text { which does not reach forwards to the } \\
\text { brain and lacks anterior pouches }\end{array}$ & + & + & + & + & + \\
\hline $\begin{array}{l}\text { Lateral intestinal diverticula present, } \\
\text { shallow }\end{array}$ & + & + & + & + & + \\
\hline $\begin{array}{l}\text { Lateral nerve cords with single fibre } \\
\text { core, without accessory nerves }\end{array}$ & + & + & + & + & + \\
\hline $\begin{array}{l}\text { Gonads located in intestinal region, } \\
\text { arranged as a single longitudinal row } \\
\text { on each side of the body }\end{array}$ & + & + & + & + & + \\
\hline $\begin{array}{l}\text { Eyes four, anterior and posterior } \\
\text { pairs widely separated }\end{array}$ & + & + & + & + & + \\
\hline Pre-cerebral septum closed & + & + & + & + & + \\
\hline \multicolumn{6}{|l|}{$\begin{array}{l}\text { B. Features which can be used to } \\
\text { distinguish between the taxa }\end{array}$} \\
\hline $\begin{array}{l}\text { Cephalic furrows present }(+) \text { or } \\
\text { absent }(0)\end{array}$ & 0 & 0 & 0 & 0 & + \\
\hline $\begin{array}{l}\text { Cephalic glands present }(+) \text { or } \\
\text { absent }(0)\end{array}$ & + & 0 & + & + & + \\
\hline Number of proboscis nerves & $?$ & 8 & $?$ & 9 & $9-10$ \\
\hline $\begin{array}{l}\text { Length of rhynchocoel as a \% } \\
\text { of the body }\end{array}$ & $50-60 ?$ & 50 & 60 & 50 & $30-60$ \\
\hline $\begin{array}{l}\text { Short dorsal nerve present }(+) \\
\text { or absent }(0)\end{array}$ & $0 ?$ & $0 ?$ & + & 0 & 0 \\
\hline $\begin{array}{l}\text { Number of muscle layers in wall } \\
\text { of main anterior proboscis chamber }\end{array}$ & $?$ & $?$ & $?$ & 3 & 2 \\
\hline $\begin{array}{l}\text { Number of accessory stylet pouches } \\
\text { in stylet bulb region of proboscis }\end{array}$ & 2 & 2 & 2 & 2 & $2-4$ \\
\hline $\begin{array}{l}\text { Junction of foregut and intestine } \\
\text { with }(+) \text { or without }(0) \text { posteriorly } \\
\text { directed dorsal foregut appendix }\end{array}$ & $?$ & $?$ & $?$ & + & 0 \\
\hline $\begin{array}{l}\text { Weakly developed dorsoventral } \\
\text { muscles present }(+) \text { or absent }(0) \\
\text { in intestinal region }\end{array}$ & + & + & 0 & $?$ & 0 \\
\hline $\begin{array}{l}\text { Rhynchodaeum at rear extending } \\
\text { below anterior part of rhynchocoel } \\
\text { as a short blind-ending sac }\end{array}$ & 0 & 0 & + & 0 & 0 \\
\hline
\end{tabular}


rhynchocoel between 30 and $66 \%$ of body length, with wall containing separate circular and longitudinal muscle layers; transverse muscle septum which forms a constriction around intestine developed from circular muscle layer of rhynchocoel wall; proboscis armature consisting of single central stylet and 2-4 accessory stylet pouches; body wall musculature without diagonal layer, longitudinal muscles not divided anteriorly; precerebral septum closed; tip of head with both circular and longitudinal body wall muscle layers; cephalic glands present or absent; cerebral organs small and simple, situated far anterior to the brain and opening near the tip of the head; lateral nerve cords with single fibre core, without accessory nerves; intestine with single anterior caecum which does not reach the brain and lacks anterior pouches, intestine with shallow lateral diverticula; blood system simple, with three postcerebral longitudinal vessels which are not linked by pseudometameric transverse connectives; four eyes, anterior and posterior pairs widely separated; sexes separate, gonads arranged in single longitudinal row on either side of the intestine; cephalic furrows present or absent.

\section{ACKNOWLEDGEMENTS}

We are grateful to $\mathrm{Dr} \mathrm{H}$. Mukai, Director of the Akkeshi Marine Biological Station, Hokkaido University, for providing the facilities for our research. We gratefully acknowledge the help of the staff of the AMBS and the kind assistance of $\mathrm{Dr} \mathrm{Y}$. Takashima, Mr T. Kato and Mr M. Shimomura in obtaining specimens. We would like to express our appreciation to Dr Janet Moore and Frank Crandall for their critical reading of the original manuscript.

\section{REFERENCES}

Friedrich H (1935a) Neue Hoplonemertinen der Kieler Bucht. Schr naturw Ver Schlesw-Holst 21: 10-19

Friedrich H (1935b) Studien zur Morphologie, Systematik und Ökologie der Nemertinen der Kieler Bucht. Arch Naturgesch 4: 293-375

Friedrich H (1936) Nemertini. Tierwelt N-u Ostsee IVd: 1-69

Friedrich H (1955) Beiträge zu einer Synopsis der Gattungen der Nemertini monostilifera nebst Bestimmungsschlüssel. Z wiss Zool 158: $133-192$

Gibson R (1972) Nemerteans. Hutchinson, London

Gibson R (1994) Nemerteans. Field Studies Council, Shrewsbury.

Gibson R (1995) Nemertean genera and species of the world: an annotated checklist of original names and description citations, synonyms, current taxonomic status, habitats and recorded zoogeographic distribution. J nat Hist 29: 271-562

Iwata F (1954) The fauna of Akkeshi Bay. XX Nemertini in Hokkaido. J Fac Sci Hokkaido Univ Srs 6 Zool 12: 1-39

Kirsteuer E (1965) Über das Vorkommen von Nemertinen in einem tropischen Korallenriff 4. Hoplonemertini monostilifera. Zool Jb Abt Syst Ökol Geogr Tiere 92: 289-326

Norenburg J L (1985) Structure of the nemertine integument with consideration of its ecological and phylogenetic significance. Am Zool 25: $37-51$

Yamaoka T (1940) The fauna of Akkeshi Bay. IX Nemertini. J Fac Sci Hokkaido Univ Srs 6 Zool 7: 205-261

(Received August 30, 1999 / Accepted October 7, 1999) 